\title{
Primary care mental health: nurses' activities in the psychosocial care network
}

\author{
Saúde mental na atenção básica: atuação do enfermeiro na rede de atenção psicossocial \\ Salud mental en la atención primária: actuación del enfermero en la red de atención psicosocial
}

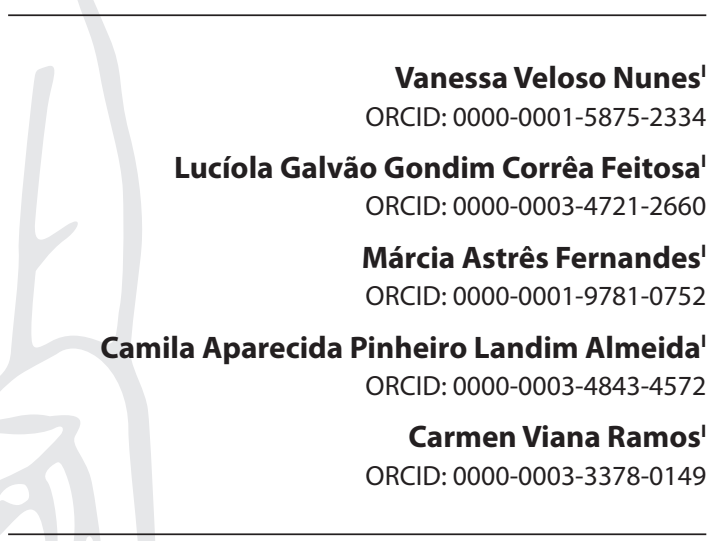

'Centro Universitário Uninovafapi. Teresina, Piauí, Brazil.

How to cite this article:

Nunes VV, Feitosa LGGC, Fernandes MA, Almeida CAPL, Ramos CV. Rev Bras Enferm. 2020;73(Suppl 1):e20190104. doi: http://dx.doi.org/10.1590/0034-7167-2019-0104

Corresponding author:

Vanessa Veloso Nunes

E-mail: vanessavelosoleite@gmail.com

EDITOR IN CHIEF: Antonio José de Almeida Filho ASSOCIATE EDITOR: Andrea Bernardes

Submission: 03-31-2019 Approval: 12-17-2019

\section{ABSTRACT}

Objective: to describe and analyze the role of expert nurses in mental health in the Family Health Strategy. Method: a qualitative study, with 20 Basic Health Units nurses of Teresina, Piauí. The information was collected through semi-structured interviews from March to May 2017 and analyzed using the content analysis method. Results: it was found that the conceptions of the mental health disease process were based on the biological model, there was little communication between mental health and basic network, nurses did not feel qualified to work mental health and there were few mental health actions in Primary Care. Final considerations: it becomes urgent to implement public policies that articulate mental health and Primary Care, raising awareness and continuing education for nurses.

Descriptors: Mental Health; Primary Health Care; Nursing; Family Health and Mental Disorders.

\section{RESUMO}

Objetivo: descrever e analisar a atuação do enfermeiro especialista em saúde mental na Estratégia Saúde da Família. Método: estudo qualitativo, com 20 enfermeiros que atuam nas Unidades Básicas de Saúde da Família de Teresina, Piauí. As informações foram coletadas por meio de entrevistas semiestruturadas no período de março a maio de 2017 e analisadas pelo método de análise de conteúdo. Resultados: constatou-se que as concepções do processo saúde doença mental estiveram fundamentadas no modelo biológico, havia pouca comunicabilidade entre saúde mental e rede básica, os enfermeiros não se sentiam capacitados para trabalhar saúde mental e havia poucas ações de saúde mental na Atenção Básica. Considerações finais: tornase urgente a efetivação de políticas públicas que articulem a saúde mental e Atenção Básica, a sensibilização e a formação continuada dos enfermeiros.

Descritores: Saúde Mental; Atenção Primária à Saúde; Enfermagem; Saúde da Família e Transtornos Mentais.

\section{RESUMEN}

Objetivo: describir y analizar la actuación del enfermero en salud mental en la Estrategia de Salud de la Familia. Método: estudio cualitativo, con 20 enfermeros que actúan en las Unidades Básicas de Salud de la Familia de la ciudad de Teresina, Piauí. Las informaciones fueron recolectadas por medio de entrevistas semiestructuradas en el período de marzo a mayo de 2017 y analizadas por el método de análisis de contenido. Resultados: se constató que las concepciones del proceso salud enfermedad mental estuvieron fundamentadas en el modelo biológico, que había poca comunicación entre salud mental y red básica, que los enfermeros no se sentían capacitados para trabajar salud mental, que había pocas acciones de salud mental en la salud Atención Primaria. Consideraciones finales: se vuelve urgente la efectividad de políticas públicas que articulen la salud mental y la Atención Primaria, la sensibilización y la formación continuada de los enfermeros.

Descriptores: Salud Mental; Atención Primaria de Salud; Enfermería; Salud de la Familia y Trastornos Mentales. 


\section{INTRODUCTION}

Primary Care is the first level of care in the Brazilian Unified Health System (SUS - Sistema Único de Saúde). As a result, we argue that it is in the Family Health Strategy (FHS) that mental health care needs to find the possibility of welcoming, incorporating, structuring and developing, which allows mental health care making it possible to overcome the historical setting of lack of assistance and maltreatment, potentializing the construction of new spaces for the production of knowledge, social, political and legal interventions in relation to the mad and madness ${ }^{(1)}$.

The Psychosocial Care Network (RAPS - Rede de Atenção Psicossocial) proposes a model that articulates several points of attention to users, such as Primary Health Care, Specialized Psychosocial Care, Transitional Residential Care, Urgency and Emergency Care, Hospital Care and psychosocial deinstitutionalization and rehabilitation strategies. FHS, in the scope of Primary Health Care, proposes the articulation between technical and popular knowledge, and the mobilization of institutional and community resources to face mental health problems ${ }^{(2-3)}$.

FHS nurses have a relevant position, as they play a proactive role in their activities and stand out as the most prepared and available professional to support and guide the patient and family in experiencing the disease, treatment and rehabilitation process ${ }^{(4)}$.

Bearing in mind that Primary Care constitutes a privileged plan for the care of mental health needs, nurses, as working directly in this service, must be prepared to assist patients with mental disorders. They must help to reduce the damage involved and their possible hospitalization, in order to guarantee an effective assistance and promote health, without losing the dignity of those suffering from mental suffering ${ }^{(5)}$.

FHS nurses need to broaden their view beyond physical health and recognize mental health as inseparable from any context and action taken. As a result, they need to improve the practice of working on integrating RAPS with the family, estimating the real needs of the community through their participation in the planning of actions. They must provide comprehensive care to the family and the patient, which may occur as practices and teaching are being reformulated ${ }^{(6)}$.

Another relevant issue is the possible gap between what is recommended in the mental health policy and what is observed in the practice of the FHS. It is noticed, with some frequency, the logic of referral to the Psychosocial Support Center (CAPS - Centro de Apoio Psicossocial) transferring care to this point of attention. This articulation represents a new challenge in the setting of public health policies in Brazil ${ }^{(7)}$.

There is a fear of care and reception for users in mental distress on the part of professional nurses. These practices and conceptions impact and delay the necessary advances in relation to Psychiatric Reform (PR) and compromise the constitution of RAPS, since RAPS will only exist effectively, articulated with other health services ${ }^{(7)}$.

Today we have a trajectory of fragmentation of the assistance network and the work process, where the low investment in professional qualification affects the nurses' unpreparedness to deal with the subjective dimension in care practices. Oftenly, it results in disrespect for users' rights ${ }^{(8)}$.

However, this can be a reflection of several associated factors: lack of understanding with mental health services that functioned as a backup and allowed quick reference in case of need; lack of knowledge about the PR movement; lack of mental health training for FHS nurses; precarious conditions for the care of these cases in Primary Care, which includes inadequate infrastructure, insufficient consumables and equipment; inexistence of an articulated mental health network, among others ${ }^{(9)}$.

CAPS in its functional proposal occupy the position of substitute services, not complementary to the psychiatric hospital. According to the definition of the Ministry of Health, CAPS constitute "institutions that welcome mentally disturbed patients, stimulate social and family integration, support autonomy initiatives, with medical and psychological assistance"(9).

Attention in the area of mental health in Primary Care and in FHS involves assisting individuals in psychological distress or with mental disorders already established and the development of preventive and early detection actions, covering patients and their families ${ }^{(10)}$.

Therefore, this work aims to gather knowledge that contributes to the practice of mental health in Primary Care. It is believed that knowing the practices of professional nurses in relation to mental health in Primary Care and articulating with the concepts of mental health and psychosocial care will allow actions and practices to become more viable in the perspective presented to primary care for the promotion and prevention of mental health.

\section{OBJECTIVE}

To describe and analyze the role of expert nurses in mental health in the FHS.

\section{METHOD}

\section{Ethical aspects}

This research followed the guidelines of Resolution 466/2012 of the Brazilian National Health Board (Conselho Nacional de Saúde), and started after approval by the Research Ethics Committee with Certificado de Apresentação para Apreciação Ética (Certificate of Presentation for Ethical Consideration). All participants were informed about the research and signed the Informed Consent Form. In the data presentation, participants' speeches received alpha numeric identifications (E1,..., E20) according to the chronological order of the interviews, ensuring their secrecy and anonymity throughout the research process.

\section{Theoretical-methodological framework}

The research was based on the multidisciplinary approach recommended in the Mental Health Policy ${ }^{(11)}$, with an emphasis on psychosocial rehabilitation and also, in professional nursing legislation ${ }^{(12)}$. 


\section{Type of study}

This is a qualitative research applied to health, through content analysis ${ }^{(13)}$. The Vancouver rules were used to guide the methodology.

\section{Methodological procedures}

\section{Study setting}

The study was carried out in the city of Teresina, Piauí, more specifically in ten (10) Basic Health Units (BHU) that operate in the urban area of the municipality of Teresina, state of Piauí and are linked to the Municipal Health Department of Teresina between August and October of 2017.

\section{Data source}

The study sample consisted of 20 nurses who worked at FHS in the BHU. Participants were chosen by convenience sampling, as long as they met the pre-defined criteria to be nurses who were part of the FHS with at least one year of professional experience, without leave of absence for more than 60 days in the last year. Nurses who were on vacation or leave during the study data collection period were excluded.

\section{Collection and organization of data}

Data collection took place from March to May 2017, by means of a response to an individual semi-structured interview prepared by the authors themselves, with questions regarding the socio-demographic profile, such as age, sex, education, education, graduation institution, year of graduation. completion of graduation, length of professional experience, working time at FHS, work regime and other employment relationships. There was an open question where nurses were asked about their participation in any course, update, qualification in mental health offered by the institution where they worked, focused on Primary Care. They were asked about the following openended questions: how do you identify the mental health needs of the population in your territory?; Is there any type of action developed by nurses in the care provided to people with mental disorders in primary care? What are they?; What is your perception about mental health care in Primary Care?; Describe the potentials and difficulties found by you in the care provided to people with mental disorders in Primary Care?

\section{Data analysis}

The answers were submitted to thematic analysis, following the stages of pre-analysis, exploration of the material, treatment of the results obtained and interpretation ${ }^{(14)}$.

The process of analyzing the information gave rise to four thematic categories: "Access to FHS in promoting mental health"; "Activities developed by nurses with mental health patients"; "Conception of BHU nurses about mental health care in Primary Care" and "Training of nurses to develop care for patients with mental disorders".
The choice of participants and locations was made in view of the peculiarity in the design of qualitative research that recommends the collection of information in environments considered relevant to the study ${ }^{(15)}$.

\section{RESULTS}

Based on the testimonies of the nurses participating in the research, the four thematic categories were identified: "Access to FHS in promoting mental health"; "Activities developed by nurses with mental health patients"; "Conception of BHU nurses about mental health care in Primary Care" and "Training of nurses to develop care for patients with mental disorders".

\section{Access to Family Health Strategy in promoting mental health and Activities developed by nurses with mental health patients}

According to the study subjects, they highlighted positive points such as the proximity between the FHS and the population, the humanistic and welcoming characteristic that emerges between the professional and the patient in the therapeutic process. These findings can be evidenced in the following statements:

You give the patient the opportunity to speak, express themselves, talk about their problems, you already see improvement in the patient. (E3)

In fact, the first service that the family comes or the patient even alone is in primary care, because most of them already have a bond with the CHA, with the nurse, with the doctor, so, mental health, it starts at primary care, not mental health illness, but mental health prophylaxis starts here. (E1)

Primary Care contemplates the users' first gateway and builds the bond of the triad professionals, users and services within the FHS program, the holistic and comprehensive performance of this level of care proposes subsidies for the recruitment of these users according to their needs.

The studied subjects were unanimous in declaring that the mental health actions implemented by them in Primary Care are still not, most of the time, punctual:

There is not. There's nothing. Nothing, nothing. The only thing we do is identify patients and refer them to CAPS. (E2)

I took that community therapy course, but I haven't yet put it into practice on my team. (E3)

With the change in the care model, there is a concern with professional training, with the aim of ensuring effective care and promoting health. However, in practice, there is resistance on the part of professionals, either because they wish to maintain traditional concepts and practices, or because they do not know how to guide their performance within the new paradigms. Professionals understand the importance of actions within Primary Health Care, however there is a difficulty in implementing the interventions in a holistic manner. 
Look, we haven't taken any action, we take advantage of some opportunities in which we approach the family, but doing work aimed at this in our strategy is not yet considered. I do not do this! (E4)

We don't do any here. So, the only thing you can do is still refer to the CAPS, so in this case, when you come here, but the one who usually does the referral is the doctor, not us, they were always done by the doctor. (E5)

It is pertinent to emphasize the importance of empowering the professional nurse and the entire Primary Health Care team to provide care to patients who need mental health care. This must occur from planning to intervention, both at the individual and collective community level. Although some participants denied their tasks, at the same time the reception, listening, professional bonds that they have when they receive demands in this sense were perceived, which is consecrated exactly as what is expected within the policy in the FHS.

\section{Conception of Basic Health Units nurses about mental health care in Primary Care}

The service to users is carried out in a timely and assiduous manner. However, the implementation of actions to be provided to patients is incipient. Thus, part of the complaints made in relation to psychiatric hospitals, also seems to echo in the BHU workers' discourse, when they state the reduction of the mental health care offer to a single aspect: the medication. It is conjectured that the interventions offered to users do not address users' needs with regard to biopsychosocial, physical and spiritual aspects.

We feel a difficulty, a group so difficult to work with, I see it like this, the concern more about giving that medicine, but there is no prevention, like that, it is not! (E3)

Women, we don't have this service here, so the perception, I think it's a very big need, but it's very difficult to monitor these patients. (E5)

In relation to mental health, nurses emphasized their limited participation in treatment decisions. They feel like active professionals, able to stipulate which are the best therapeutic strategies for each user individually, within Primary Care.

The assistance provided within Primary Care health services involves primarily the use of medications. It is inferred that this reality is a reflection of the cultural roots inherent in the care provided by professionals based on the hospital-centered model, which often do not match the biopsychosocial needs in the face of this problem in patients with affected mental health.

The professional reports what is really important as a form of mental health care, as follows in the report in this regard:

How many times you don't need medicine, you need some attention and we in the Family Health Program [Programa Saúde da Familia] have this access ... because sometimes it is a situation like a meeting, a conversation, a welcoming. (E4)
All of this condition generates concern for professionals because they are unable to act actively in the work environment. The articulation with the multidisciplinary and interdisciplinary team strengthens the decision-making for the choice of intervention strategies in order to mitigate the impasses and propose a subsidy for the quality of care provided to patients.

However, we are also very burdened with other services, so mental health is as if it were not the same value as a service, a hypertensive patient, a pregnant woman, you know! (E8)

The nurse is often involved only with the bureaucratic part of the service. The lack of personnel in the units ends up overloading the professional who is forced to leave aside the user who is entitled to comprehensive care. (E4)

\section{Training of nurses to develop care for patients with mental disorders}

According to the subjects, they highlight the difficulty in dealing with patients with mental disorders. From the break with the traditional psychiatric model, a crisis of identity of the nurse appears, which is lost in relation to practices in the psychosocial field, which is reported in the following statements:

One of our difficulties is precisely more training in the area of mental health, as we usually have few skills. (E1)

\section{Difficulties are referrals, it is finding support, guidance. (E2)}

One of the main difficulties cited by the interviewees for their work in mental health was the lack of definition of the nurse's identity in the psychosocial area, within the new model.

We feel a difficulty, a group so difficult to work. At FHS, both nurses and doctors have great difficulty with this public. (E3)

Many limitations we have, lack of knowledge, we end up leaving it up to the other programs that we have to attend to too and we feel a little, I say even unprepared to work in mental health care. (E14)

It is possible to highlight that the nurses interviewed reported that they had not undergone any specific training to assist patients with mental disorders and their families in Primary Care. Most reported only a few experiences in the undergraduate course, but very meaningless. Although all reported having received such content, to care for the mentally ill, they reported that they were insufficient to work with patients who live with mental disorders.

\section{DISCUSSION}

FHS is an important device of the mental health care network to promote the concreteness of deinstitutionalization, proposed by the movement of the most avant-garde of PR, for allowing community and territory care, centered on people and their contexts, social and family ${ }^{(16)}$.

Primary Health Care is a strategic axis for the insertion of mental health actions and a fertile field for this new way of 
thinking about health, involving a network of actors with different knowledge and practices and further strengthening SUS guiding principles ${ }^{(17)}$.

It could be seen that the implementation of various actions in mental health by nurses has been taking place gradually in Primary Care, but they are still very incipient, being, in most cases, punctual, focused on drug assistance and not having them as active professionals. in this therapeutic process.

They reported in this study that they did not feel fit, due to the lack of preparation regarding training courses, training and updating, mainly due to lack of support from managers or even the absence or deficiency of this content in their academic or professional training, or even lack of referral flow from individuals within the health network and difficulty in referring patients.

Mental health care, mainly through the provision of medication and medical consultation, is reiterated as insufficient when it comes to assistance that must be offered outside hospitalcentered standards. In view of the mismatch between what is provided for in the texts that regulate public mental health policies and the working conditions available in a $\mathrm{BHU}$, the identification of innovative practices by health professionals is necessary to consolidate the knowledge necessary to advance PR and the organization of mental health care ${ }^{(5)}$.

It is relevant to highlight that the nurse together with the entire health team must know the profile of this clientele, helping the planning and execution of mental health actions both at the BHU level and in the community. It is necessary for nurses to reflect on what is already happening daily and what the territory has to offer as a resource that can contribute to the management of these issues ${ }^{(18)}$.

Seeking to understand how patients with mental disorders are cared for by nurses is important, since, in this way, one can contribute to the improvement of mental health actions at FHS.

The mental health interventions carried out by nurses should promote new possibilities to modify and qualify the conditions and ways of life of people with mental disorders, guided by the production of life and health and not restricted to curing diseases. This means believing that life can have different ways of being perceived, experienced and lived ${ }^{(19)}$.

Nurses need to be prepared to serve all types of users and give them humanized and holistic support, expanding the possibilities and potential of users, family members, professionals and community. Nursing, as a profession that makes up the health team, in this new setting, is invited to go beyond the actions of containing, monitoring and medicating, which for so many years summarized their participation in the mental health care process ${ }^{(20)}$. It is worth mentioning that the policy does not determine the training of nurses for the psychosocial model, the policy recommends the training of professionals to work within SUS.

Despite the importance of the professional nurse's performance, the demand for activity within still represents a gap between the identification of the problem and the performance within the community. In the field of care, nurses are closer to the patient, thus becoming a great reference for most patients with mental disorders. They are required a great deal of attention from which, many times the nursing professional is not able to provide the requested service causing professional dissatisfaction $^{(20-21)}$.

In view of this, we can conclude that there are gaps in the training of nurses (general practitioners) to participate in the development of actions to promote mental health, prevention and treatment of people with mental disorders. Therefore, we can emphasize that the health system needs specialist nurses in mental health, capable of leading in this area and coordinating specific actions, in a multidisciplinary environment.

\section{Study limitations}

Although the research was carried out with a small number of participants, which can be considered a limitation of this research, the results found can support the realization of other studies that broaden the discussion about the mental health care of nurses in Primary Care and also in other areas where this professional works.

\section{Contributions to nursing, health or public policy}

Nurses are seen as a key element for FHS establishment in Primary Care. With this, it becomes necessary to objectively define the range of specialized skills to be developed by nurses, namely those specialized in mental health and psychiatry, contributing to the advancement of nurses' debates, teaching and practices.

\section{CONCLUSION}

This study made it possible to approximate the reality experienced by nurses who work in BHUs in relation to the care of patients with mental health and their families. The results of this research showed that mental health care demands in Primary Care are a reality. Primary Care is a promising territory for the effectiveness of the psychosocial care network for the subject, family and community.

An important point in the reality of Primary Care in Brazil, which needs to be urgently reviewed is to train nursing professionals to care for patients with mental disorders and their families. In addition to the verification of the absence of a network between the services of health care levels that should complement and refer to effectively.

It was also possible to perceive that the participating nurses work in mental health with psychiatric concepts based on the biological model - evidencing the need to break with this model of care, being essential that these concepts and behaviors are deconstructed.

Thus, the need for services to be known is highlighted, as well as their difficulties and potential for mental health care in Primary Care, in order to develop a practice of care for patients with mental disorders that can be effective and qualified. A more in-depth approach to this topic is recommended in nursing courses in order to reduce prejudice and engage more nurses to qualify in this field, for the benefit of the quality of life of a group not only historically excluded, but unjustly suffered because of the ignorance that has long surrounded it. 


\section{ERRATUM}

Article "Primary care mental health: nurses' activities in the psychosocial care network", with number of DOl: http://dx.doi. org/10.1590/0034-7167-2019-0104, published in the journal Revista Brasileira de Enfermagem, 73(Suppl 1): e20190104, on page 1:

Where to read:

\section{Carmem Viana Ramos'}

Read:

\section{Carmen Viana Ramos'}

And, where to read:

How to cite this article:

Nunes VV, Feitosa LGGC, Fernandes MA, Almeida CAPL, Ramos CV. Rev Bras Enferm. 2020;73(Sppl 1):e20190104.

doi: http://dx.doi.org/10.1590/0034-7167-2019-0104

Read:

How to cite this article:

Nunes VV, Feitosa LGGC, Fernandes MA, Almeida CAPL, Ramos CV. Rev Bras Enferm. 2020;73(Suppl 1):e20190104.

doi: http://dx.doi.org/10.1590/0034-7167-2019-0104

\section{REFERENCES}

1. Oliveira EC, Medeiros AT, Trajano FMP, Chaves Neto G, Almeida SA, Almeida LR. O cuidado em saúde mental no território: concepções de profissionais da atenção básica. Esc Anna Nery. 2017; 21(3): e20160040. doi: 10.1590/2177-9465-EAN-2017-0040

2. Soratto J, Pires DEP, Dornelles S, Lorenzetti J. Estratégia saúde da família: uma inovação tecnológica em saúde. Texto Contexto Enferm. 2015;24(2):584-92. doi: 10.1590/0104-07072015001572014

3. Ministério da Saúde (BR). Portaria n 3.088, de 23 de dezembro de 2011. Institui a Rede de Atenção Psicossocial para pessoas com sofrimento ou transtorno mental e com necessidades decorrentes do uso de crack, álcool e outras drogas, no âmbito do Sistema Único de saúde (SUS). Diário Oficial da União, Brasília, DF, 23 dez. 2011.

4. Santos TRA, Souza SR. Nursing interventions for children and adolescents with cancer during the chemotherapy treatment. Rev Pesqui Cuid Fundam. 2015;7(3):28532864. doi: 10.9789/2175361.2015.v7i3.2853-2864

5. Souza MC, Afonso MLM. Saberes e práticas de enfermeiros na saúde mental: desafios diante da Reforma Psiquiátrica. Gerais: Rev Interinst Psicol [Internet]. 2015 [cited 2016 Jan 15];8(2):332-47. Available from: http://pepsic.bvsalud.org/pdf/gerais/v8n2/v8n2a04.pdf.

6. Pires LF, Macedo L, Aleluia Jr J, Freitas PH, Cavalcante R, Machado R. Estratégia saúde da família e assistência ao dependente químico: ações conjuntas ou isoladas?. Rev Eletrônica Enferm. 2016;28:1-11. doi: 10.5216/ree.v18.39177

7. Ministério da Saúde (BR). Portaria no 3088 de 23 de dezembro de 2011. Institui a Rede de Atenção Psicossocial para pessoas com sofrimento ou transtorno mental e com necessidades decorrentes do uso de crack, álcool e outras drogas, no âmbito do Sistema Único de Saúde [Internet]. Brasília: 2011 [cited 2016 Jan 15]. Available from: http://bvsms.saude.gov.br/bvs/saudelegis/gm/2011/prt3088_23_12_2011_rep.html

8. Ministério da Saúde (BR). Secretaria de Atenção à Saúde, Departamento de Ações Programáticas Estratégicas. Caderno Humaniza SUS: Saúde Mental. Brasília: Ministério da Saúde; 2015. 548 p.

9. Corrêa SAS. A Importância do Enfermeiro para Pacientes Mentais no Centro de Atendimento Psicossocial (CAPS). Rev Cient Multidisc Núcleo Conhec [Internet]. 2017 [cited 2016 Jan 15]; 2(13):395-416. Available from: https://www.nucleodoconhecimento.com.br/saude/ enfermeiro-pacientes-mentais

10. Bardin L. Análise de conteúdo. Lisboa; Edições 70; 2013.

11. Ministério da Saúde (BR). Portaria n 3088 de 23 de dezembro de 2011. Institui a Rede de Atenção Psicossocial para pessoas com sofrimento ou transtorno mental e com necessidades decorrentes do uso de crack, álcool e outras drogas, no âmbito do Sistema Único de Saúde [Internet]. Brasília: 2011 [cited 2016 Jan 15]. Available from: http://bvsms.saude.gov.br/bvs/saudelegis/gm/2011/prt3088_23_12_2011_rep.html 
12. Conselho Federal de Enfermagem. Resolução n. 358, de 15 de outubro de 2009. Dispõem sobre a SAE e a implementação do processo de enfermagem [Internet]. Brasília. 2009 [cited 2016 Sep 30]. Available from: http://www.cofen.gov.br/resoluocofen-3582009_4384.html

13. Minayo MCS. O desafio do conhecimento: pesquisa qualitativa em saúde. 9 ed. São Paulo: E. Hucitec; 2008.

14. Minayo MCS. O desafio do conhecimento: pesquisa qualitativa em saúde. 13 ed. São Paulo: Hucitec; 2013.

15. Oliveira EC, Medeiros AT, Trajano FMP, Chaves Neto G, Almeida SA, Almeida LR. Mental health care in the territory: conceptions of primary health care professionals. Esc Anna Nery[Internet]. 2017 [cited 2016 Jan 15];21(3):e20160040. Available from: https://www.ncbi.nlm.nih.gov/ pmc/articles/PMC2777564/pdf/MHFM-05-075.pdf

16. Mota AS, Silva ALA, Souza ÂC. Educação permanente: Práticas e processos da enfermagem em saúde mental. Rev Port Enferm Saúde Mental. 2016;(spe4):916. doi: 10.19131/rpesm.0135

17. Andrade JMO, Rodrigues CAQ, Carvalho APV, Mendes DG, Leite MT. Multiprofessional care to mental disorder patients under the perspective of the family health team. Rev Pesqui Cuid Fundam. 2013;5(2):3549-57. doi: 10.9789/2175-5361.2013v5n2

18. Wenceslau LD, Ortega F. Mental health within primary health care and Global Mental Health: international perspectives and Brazilian context. Interface (Botucatu). 2015;19(55):11211132. doi: 10.1590/1807-57622014.1152

19. Ministério da Saúde (BR), Secretaria de Atenção à Saúde, Departamento de Atenção Básica. Cadernos de Atenção Básica: Saúde mental. Brasília: Ministério da Saúde; 2013; 34: 176 p.

20. Alves SR, Santos RP, Gimenes RMT, Yamaguchi MU. Sobrecarga De Trabalho Da Enfermagem Em Saúde Mental. Rev Rene. 2016;17(5):684-90. doi: 10.15253/2175-6783.2016000500014

21. Carrara GLR, Moreira GMD, Facundes GM, Pereira RS, Baldo PL. Assistência De enfermagem humanizada em saúde mental: uma revisão da literatura. Rev Fafibe [Internet]. 2015 [cited 2016 Jan 15];8(1):86-107. Available from: http://unifafibe.com.br/revistasonline/arquivos/ revistafafibeonline/sumario/36/30102015183642.pdf 